\title{
Processing Dewatered Faecal Sludge into Un Pelletized Fertilizer for Crop Production in Greater Accra-Ghana
}

\author{
Dennis Ofori-Amanfo ${ }^{1}$, George Nana Kwesi Rockson ${ }^{2}$, Alfred Arthur ${ }^{3}$, Issahaku Ahmed ${ }^{1, *}$ \\ ${ }^{1}$ Sewerage Systems Ghana Ltd., Accra, Ghana \\ ${ }^{2}$ Zoomlion Ghana Ltd., Accra, Ghana \\ ${ }^{3}$ Cocoa Research Institute of Ghana, Akim Tafo, Ghana
}

Email address:

oblon13@hotmail.com(D. Ofori-Amanfo),grockson@yahoo.com(G. N. K. Rockson), alfredarthur76@yahoo.com(A. Arthur), eagleskertoozer@yahoo.co.uk(I. Ahmed)

${ }^{*}$ Corresponding author

\section{To cite this article:}

Dennis Ofori-Amanfo, George Nana Kwesi Rockson, Alfred Arthur, Issahaku Ahmed. Processing Dewatered Faecal Sludge into Un Pelletized Fertilizer for Crop Production in Greater Accra-Ghana. International Journal of Environmental Monitoring and Analysis. Vol. 6, No. 1, 2018, pp. 18-25. doi: 10.11648/j.ijema.20180601.13

Received: February 28, 2018; Accepted: March 14, 2018; Published: April 13, 2018

\begin{abstract}
Organic wastes such as Fecal Sludge (FS) and Municipal Solid Waste (MSW) are readily available in large quantities in the Ghanaian environment especially in urban cities and towns where human populations are constantly swelling like Accra, Ghana. These wastes are observed to be rich in good amounts of organic matter and nutrients which when treated and managed well can be reused in agricultural production by improving soil fertility for plant growth. This study seeks to present first extensive assessment of the physicochemical and Microbial characteristics of mixing dried Fecal Sludge (DFS) and municipal organic Compost and the formulation mix effect on lettuce production in greater Accra region. Analysis of the characteristics of Dry Fecal Sludge and Compost informed in three (3) different formulations of Mix accordance with estimated variation on percentage nitrogen of $1.5 \%, 2.0 \%$ and $2.5 \%$. The ratios were 1:3.3, 1:1.1 and 1:0.4 (w/w) of Dry Fecal Sludge and Compost respectively. Analyses of the physicochemical parameters confirmed that, formulation Mix of Dry Fecal Sludge and Compost had significant effect $(p<0.05)$ on physicochemical parameters studied. The different treatments mix were tested on the growth of lettuce. Data on plant height and girth showed that there was a significant $(p<0.05)$ variation between the treatments. Formulated mix 1 showed high growth yield of lettuce as compared to other treatments in terms of number of leaf, wet and dry weigh of lettuce.
\end{abstract}

Keywords: Compost, Dried Fecal Sludge, Un Pelletized, Fertilizer, Agricultural Production

\section{Introduction}

Sanitation, waste and water services are increasingly becoming very relevant in most developing countries as the world's population persistently increase. The issues of sanitation are rapidly gaining grounds in sub-Sahara Africa (SSA) and Ghana is no different. Areas of major concern when it comes to population bloating are sanitation and waste management in the urban and peri-urban centers as well as food security of the people. Sandec [1] reported that in the next fifteen (15) years, urban population is expected to double both in numbers and in size. This therefore is a wakeup call to relevant stakeholders especially policy makers to come out with appropriate policies and measures aimed at curbing the foreseeable implications of bloating urban population on both food security and environmental management (sanitation). Indiscriminate disposal of sewage sludge and fecal sludge in the cities of world-nations is very problematic as thousands of tons of sludge's are disposed-off untreated [2].

About 80 percent of FS and wastewater generated nationwide are let go untreated [3]. Only $13 \%$ of the Ghanaian population were using an improved sanitation facility as at 2008 [4]. It is believed that poor sanitation costs Ghana about \$290 million per year according to a desk study carried out by the Water and Sanitation Program [5 - 6]. An average of $700 \mathrm{~m}^{3}$ of FS from an average of 100 tankers is 
disposed of at Korle Gonno every day in the capital [3]. According to Boot \& Scott, (2008) cited in [3] over 200,000 $\mathrm{m}^{3}$ of FS was disposed into the marine environment in 2006. Current studies [7] reveals that an average of 200 cesspit emptiers disposed of at the Lavender Hill Faecal treatment Plant every day. This represents a huge chunk of plant nutrients going waste and at the same time causing serious environmental pollution [3]. The foregoing arguments, evident in various studies conducted in Ghana suggest that FS is a very important raw material useful for composting.

In Sub-Saharan Africa, FS treatment end product markets have been identified as an industrial fuel, as a source of protein for animal feed, for producing biogas, as a component in building materials, and as fertilizer [1]. The current study seeks to analyze the effects of dry sewage sludge with organic compost and optimizing the palletization of the combined product for the purposes of boosting agricultural productivity through enhancing soil fertility when applied as fertilizers. This is useful in this era of scarce resources and growing impact of harsh climate conditions on agricultural productivity and the entire wellbeing of people especially the rural poor. Sewage sludge/municipal wastewater containing fecal matter is processed to reduce pathogens by at least ninety percent and transformed into very important product such as an amendment to agricultural land [8].

Sustainable crop production in the agricultural sector aimed at ensuring food security and protecting the environment has a direct link with soil fertility. Soil fertility is properly maintained by soil organic matter [3]. Adamtey et al., (2010) opine that to sustain high crop production for the sake of food security, protecting the environment; soil organic matter; soil nutrient and water resource need to be properly managed. The works of Gbenatey [3] reported that due to challenges of soil infertility in the Ghanaian agricultural setting, there seems to be heavy reliance on inorganic fertilizers as a means of replenishing soil fertility and to provide required nutrients for plant growth.

Inasmuch as fecal sludge contains plant nutrients, the untreated sludge also contains high pathogen concentrations making it dangerous for use without prior treatment as it puts both farmers and consumers at peril of diseases arising from pathogenic infections [9]. Hence treating the raw waste and dewatering and co-composting is imperative for safe use of the FS in agricultural production.

\section{Materials and Methods}

\subsection{Study Area}

The research involved both field and laboratory studies. The field experiments were conducted at the Lavender Hill fecal treatment plant site at James Town; which is demarcated as a sanitary site by the Accra Metropolitan Assembly. The laboratory studies were conducted at the Center for Scientific and Industrial Research (CSIR) Water Research Institute Laboratory in Accra. The most widely used methods of solid waste disposal in the Metropolis is collected from home (57.4\%) and by public dump (container) accounting to 32.9 percent. Liquid waste is mostly disposed into gutters $(48.0 \%)$, through a drainage system into a gutter $(26.6 \%)$ and through a sewerage system $(7.8 \%)$ which covers $42 \%$ of the population in Accra.

\subsection{Treatments Preparation}

Dewatered fecal sludge material was obtained from digesters with capacities of $4 \mathrm{~m}^{3}$ which was poured onto a $7 \mathrm{~m}$ $\mathrm{x} 120 \mathrm{~m}$ wide of concrete-drying bed. When most of the water content has drained out of the FS, $0.2 \mathrm{~m}^{3}$ of the partially dried FS was sampled from the drying bed for further drying using a $4 \mathrm{~m} \times 2 \mathrm{~m}$ raised board (figure 1). The drying process was done for a period of three (3) months. A $6 \mathrm{~m} \times 4 \mathrm{~m}$ polystyrene material was used as a covering during the drying process to ensure that the drying process was exempted from rains and other related nuisance (Figure 2). The drying process was done during the dry season (March-May) with a daily average temperature of $30^{\circ} \mathrm{C}$.

Organic compost was sampled from Accra Compost and Recycling Plant (ACARP), (Figure 3) in Adjen Kotoku in the Ga West Municipal City. Organic fractions of the Greater Accra solid waste brought to the treatment facility was sorted, composted and bagged for sale by ACARP. Physicochemical characteristics of dry fecal sludge and compost was analyzed prior to formulation mix.

Compost and DFS was mixed on a concrete floor lined with poly-sheet to ensure homogeneity (figure 5). Application rates were conducted using the appropriate mass balance proportions for the Greenhouse experiment in 20 experimental boxes (Dimensions, $30 \mathrm{~cm} \mathrm{X} 30 \mathrm{~cm}$ ): Factors of treatment included nitrogen contents.

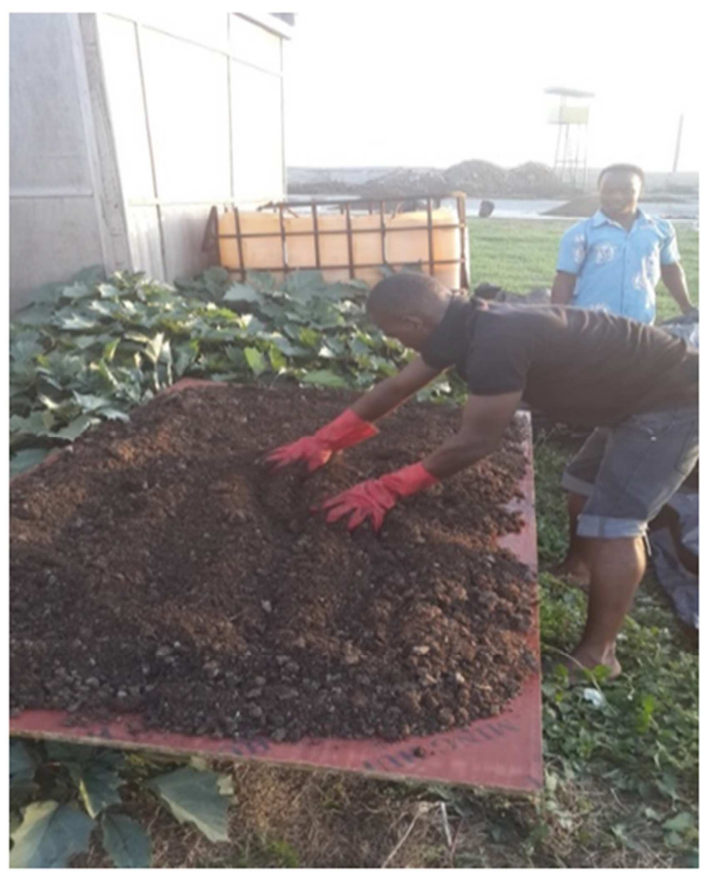

Figure 1. Drying process of FS. 


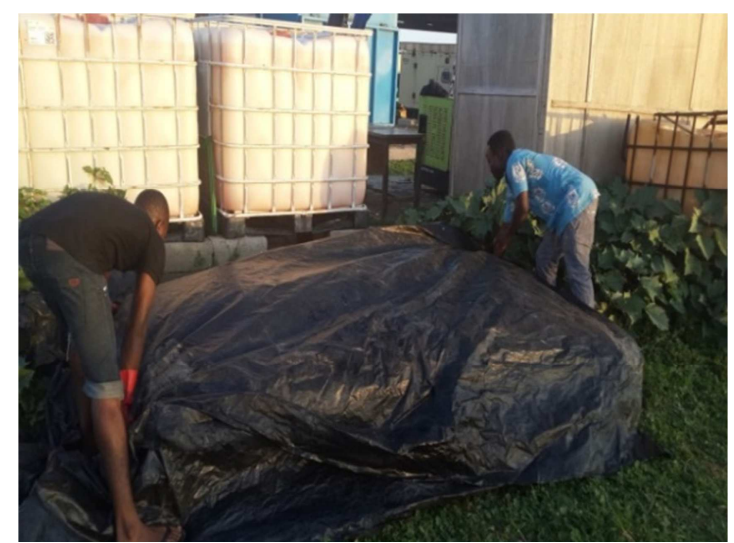

Figure 2. Protecting the DFS from the element of the weather.
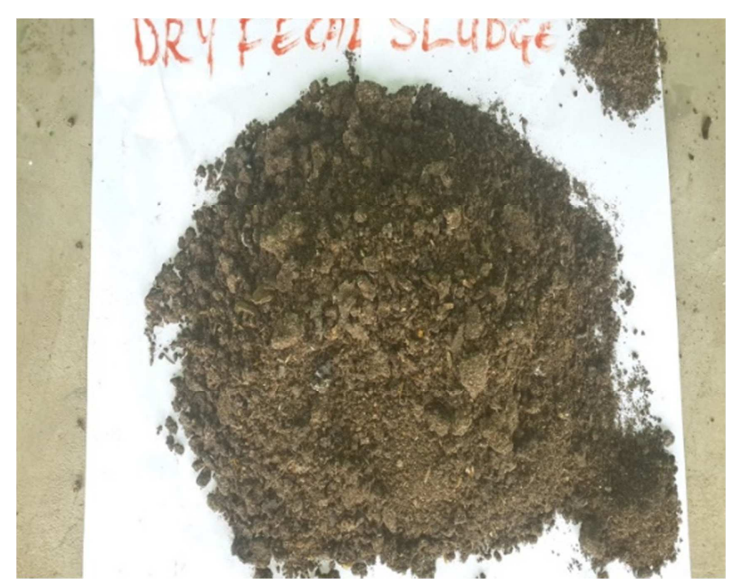

Figure 3. Dry faecal sludge.

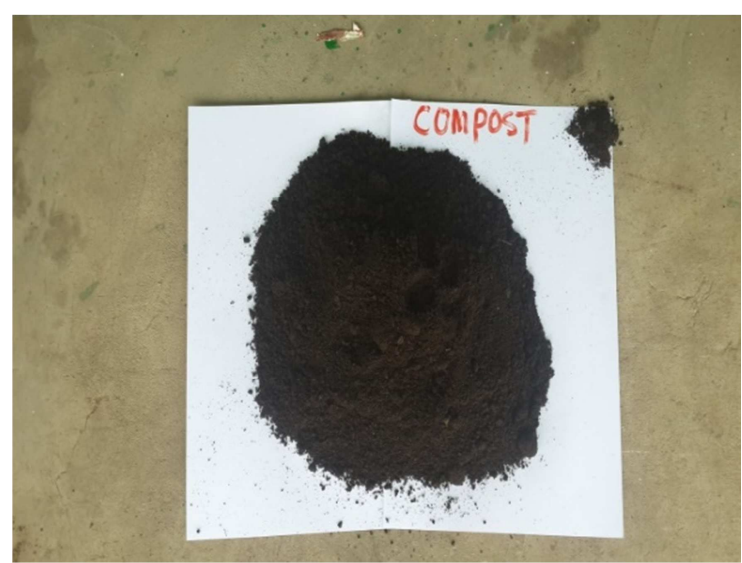

Figure 4. ACARP compost.

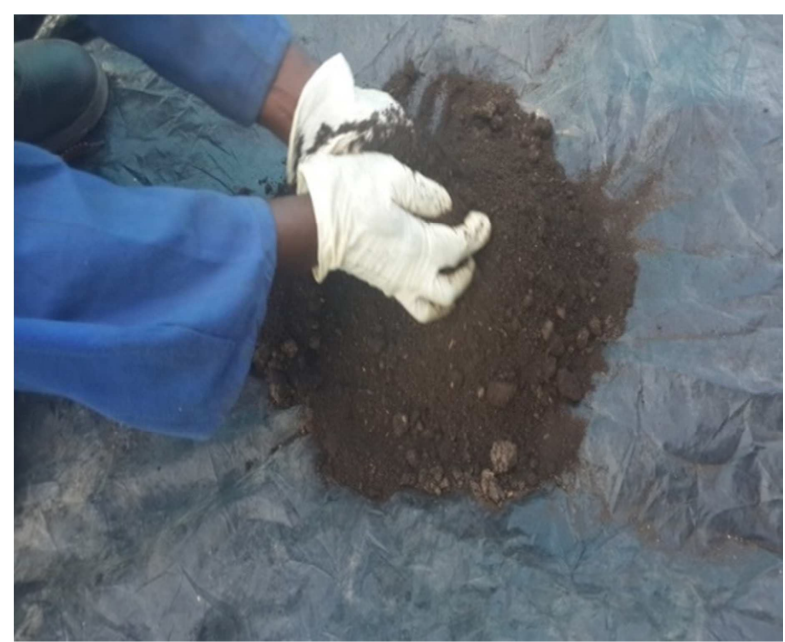

Figure 5. Mix sample preparation.

\subsection{Sampling and Analysis Methods}

A total of three samples were collected from each treatment, homogenized and ground. Samples were analyzed at $105^{\circ} \mathrm{c}$ dry basis for the following parameters: $\mathrm{MC}\left(105^{\circ} \mathrm{C}\right.$ for $24 \mathrm{~h}$ ); ash content (expressed as a percentage of residues after combustion at $550^{\circ} \mathrm{C}$ for $1 \mathrm{~h}$ ); $\mathrm{pH}$ was measured using digital $\mathrm{pH}$ meter (Metrohm model $691 \mathrm{pH}$ meter); total nitrogen (TN) using regular-Kjeldahl method [10]; the total carbon content (was determined by the dichromatometric oxidation method) total potassium (TK) (after acid digestion) using an atomic absorption spectrophotometer (Model Alpha 4), [11]; total phosphorus (TP) (after acid digestion) using ultra-violet visible, [11]; metal concentrations $(\mathrm{Zn}, \mathrm{Cu}$, and Pd ) were determined using a thermo scientific Atomic Absorption Spectrometer (AAS). Helminth egg [12] total/faecal coliform [11].

\subsection{Treatments Mix Preparations}

Samples of DFS and compost were taken to the lab for analysis of both physicochemical (TC, TP, K, C/N) and microbial (Helminth egg, TC, E. Coli) parameters (table 4)

Analysis of physicochemical characteristics of dry Fecal Sludge and Compost (Table 2), informed in three (3) different formulations of Mix preparation (figure 3) accordance with estimated variation in percentage Nitrogen of 1.5, 2.0 and 2.5 (Eq. 1). In order to obtain a uniform mixture, hands protected with hard polystyrene gloves was used to manually and thoroughly mix up the mixture. Three replications were conducted for all treatments.

Table 1 shows the composition of each formulation mix.

$$
\% N \text { on mix }=\frac{\text { Weight of Compost } \times \% N \text { Compost }+ \text { Wgt DFS } \times \% N \text { DFS }}{\text { Weight Compost }+ \text { Weight DFS }}
$$

\subsection{Laboratory Analysis}

Physico-chemical characteristics (TC, pH, MC, TN, TP, K) in the samples were determined in the dry sludge (A) and compost (B). Heavy metal ( $\mathrm{Zn}, \mathrm{Cu}$ and $\mathrm{Pd}$ ) and Microbial (fecal coliform, Helminth egg and E.coli) concentrations in dry faecal sludge and compost were analyzed. All analyses were carried out with three replicates per sample

\subsection{Lettuce Response Trial}

The different fecal- compost mixtures were tested on lettuce plant. The treatments tested consisted of (Soil only, 
Soil-Compost; Soil-DFS, DFS-Compost). The experiment was arranged in a completely randomized design (CRD) with three (3) replicates consisting of 8 seedlings per box. The design consisted of five percentage concentrations of nitrogen on organic fertilizer (Compost, DFS, DFS-Compost formulation mix), (1, 1.5, 2, 2.5 and 3\%) applied to the substrate at planting.

Eighteen experimental boxes of dimensions $30 \mathrm{~cm} \mathrm{x}$ $30 \mathrm{~cm} \times 20 \mathrm{~cm}$ was made from five divisions of $150 \mathrm{~cm} \times$ $30 \mathrm{~cm}$ width box prepared with $1 \frac{1}{2}$ inch polyline plywood. These were prepared at the Lavender Hill Faecal Treatment Plant Site for the cultivation of lettuce. Approximately eight lettuces of average high $3.2 \mathrm{~cm}$ seedlings were planted in each box. $0.025 \mathrm{~kg}$ of each treatment was uniformly spread on each of the eighteen boxes. As a control for the experiment, $0.25 \mathrm{~kg}$ of soil was used to fill two experimental boxes and was labelled no treatment. Lettuce seedlings were watered three times daily, morning, afternoon and evening. The arrangement is shown in figure 6 . The lettuce was grown for approximately four weeks before it reached maturation. Data was taken on the number of leaves, girth, height and yield of lettuce at one week interval for the four weeks of lettuce planting in each experimental setup. The average number, girth, and height of lettuce leaves from each experimental box was determined by randomly selecting six samples for physical assessment of the various characteristics mentioned.

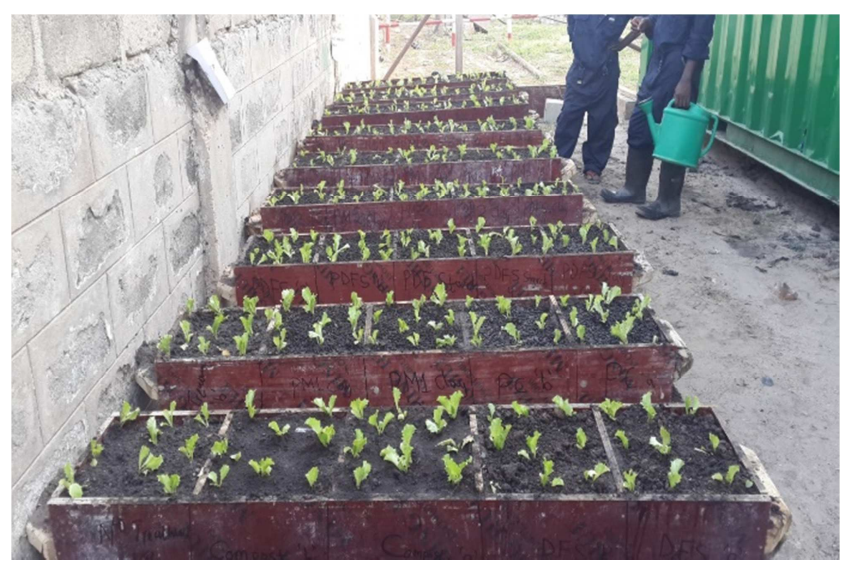

Figure 6. Lettuce planting.

\subsection{Data Analyses}

Data collected were subjected to analysis of variance (ANOVA) using GenStat 9th Edition statistical package as captured in table 2. Treatment means were compared using Least Significant Difference (LSD) at $\alpha=0.05$.

\section{Results}

Table 1. Formulation Mix Composition.

\begin{tabular}{llllll}
\hline Samples & Treatment & DFS & Compost & Ratio(w/w) & Composition \\
\hline Unit & $\% \mathrm{~N}$ & $\mathrm{~g}(\%)$ & & - & Soil \\
M0 (1) & - & - & - & - & C \\
M0 (2) & 1.04 & - & - & - & DFS \\
M0 (3) & 3.01 & - & $1000(76.7)$ & $1: 3.3$ & DFS + C \\
M1 & 1.5 & $303(23.3)$ & $1000(51.8)$ & $1: 1.1$ & DFS + C \\
M2 & 2.0 & $930(48.2)$ & $1000(26.3)$ & $1: 0.4$ & DFS + C \\
M3 & 2.5 & $2808(73.7)$ & & \\
\hline
\end{tabular}

Values in parenthesis (), are the percentage weight composition of material used in the formulation of mixed Samples; M0 (1, 2, 3) represent soil, compost and dry faecal sludge respectively.

Table 2. Effect of treatment on physicochemical characteristics of DFS, Compost and formulated Mix.

\begin{tabular}{|c|c|c|c|c|c|c|c|c|c|}
\hline Treatment & MC(\%) & OM(\%) & $\operatorname{Ash}(\%)$ & pH & TC(\%) & TN(\%) & $\mathrm{C} / \mathbf{N}$ & TP (\%) & K (\%) \\
\hline Compost & $17.7 \mathrm{abc}$ & $35.9 b$ & $64.1 \mathrm{~b}$ & $7.70 \mathrm{~d}$ & $11.93 \mathrm{~b}$ & $1.037 \mathrm{ab}$ & $11.5 \mathrm{~b}$ & $0.0178 \mathrm{a}$ & $3.387 \mathrm{c}$ \\
\hline M0(3) & $3.20 \mathrm{ab}$ & $53.7 \mathrm{c}$ & $46.3 a$ & $6.280 \mathrm{a}$ & $35.20 \mathrm{~d}$ & $3.027 \mathrm{~d}$ & $11.63 \mathrm{~b}$ & $0.1267 \mathrm{c}$ & $1.470 \mathrm{a}$ \\
\hline M 1 & $32.3 \mathrm{bcd}$ & $54.9 \mathrm{c}$ & $45.1 \mathrm{a}$ & $7.073 \mathrm{c}$ & $10.29 \mathrm{ab}$ & $1.527 \mathrm{~b}$ & $6.74 a$ & $0.0633 b$ & $4.660 \mathrm{~d}$ \\
\hline M 2 & $34.4 \mathrm{~d}$ & $62.9 \mathrm{c}$ & $37.1 \mathrm{a}$ & $6.770 \mathrm{~b}$ & $14.30 \mathrm{bc}$ & $2.130 \mathrm{c}$ & $6.71 \mathrm{a}$ & $0.00813 b$ & $4.653 d$ \\
\hline M 3 & $23.7 \mathrm{bcd}$ & $59.8 \mathrm{c}$ & $40.2 \mathrm{a}$ & $6.577 b$ & $16.50 \mathrm{c}$ & $2.450 \mathrm{~cd}$ & $6.74 a$ & $0.0658 \mathrm{~b}$ & $3.520 \mathrm{c}$ \\
\hline M0(1) & $5.6 \mathrm{a}$ & $10.2 \mathrm{a}$ & $89.8 \mathrm{c}$ & $7.507 \mathrm{~d}$ & $6.5 \mathrm{a}$ & $0.558 \mathrm{a}$ & $11.23 \mathrm{~b}$ & $0.3373 d$ & $2.287 \mathrm{~b}$ \\
\hline LSD & 16.53 & 17.18 & 17.18 & 0.2689 & 4.178 & 0.5897 & 1.168 & 0.031 & 0.607 \\
\hline P-Value & 0.011 & 0.001 & $<0.001$ & $<0.001$ & $<0.001$ & $<0.001$ & $<0.001$ & $<0.001$ & $<0.001$ \\
\hline
\end{tabular}

LSD for comparing means at the same level of treatment ( $5 \%$ level of significance): 6.415 . For each variable, means followed by the same letter are in the same range and exhibits similar treatment effect. 
Table 3. Treatment effect on metal concentrations.

\begin{tabular}{lllll}
\hline Treatment & Pb(g/kg) & Zn $(\mathbf{g} / \mathbf{k g})$ & Fe $(\mathbf{g} / \mathbf{k g})$ & $\mathbf{M n}(\mathbf{g} / \mathbf{k g})$ \\
\hline Compost & $0.135 \mathrm{ab}$ & $1.633 \mathrm{~d}$ & $7.15 \mathrm{ab}$ & $0.625 \mathrm{c}$ \\
DFS & $0.042 \mathrm{a}$ & $0.706 \mathrm{~b})$ & $0.104 \mathrm{a}$ \\
MIX 1 & $0.094 \mathrm{a}$ & $1.450 \mathrm{~cd}$ & $8.08 \mathrm{ab}$ & $0.421 \mathrm{~b}$ \\
MIX 2 & $0.123 \mathrm{ab}$ & $1.590 \mathrm{~d}$ & $6.76 \mathrm{a}$ & $0.717 \mathrm{c}$ \\
MIX 3 & $0.083 \mathrm{a}$ & $1.183 \mathrm{c}$ & $0.760 \mathrm{c}$ & $0.293 \mathrm{~b}$ \\
SOIL & $0.227 \mathrm{~b}$ & $0.333 \mathrm{a}$ & $7.05 \mathrm{a}$ & $0.387 \mathrm{~b}$ \\
LSD & 0.1139 & 0.346 & $89.8 \mathrm{c}$ & $0.167 \mathrm{a}$ \\
P-Value & 0.061 & $<0.001$ & 7.435 & $0.150 \mathrm{a}$ \\
\hline
\end{tabular}

LSD for comparing means at the same level of treatment (5\% level of significance):4.178.

For each variable, means followed by the same letter are found to be in the same rangeand exhibits similar treatment effects.

Table 4. Treatment effect on microbial concentrations.

\begin{tabular}{llll}
\hline Treatment Unit & Helminth Egg (HE) egg/20g & Fecal coliform (FC) cfu/1g & E. coli $($ E.c $)$ cfu/lg \\
\hline Compost & $2 \mathrm{a}$ & $8279 \mathrm{~b}$ & $524 \mathrm{c}$ \\
DFS & $10 \mathrm{ab}$ & $837 \mathrm{a}$ & $6 \mathrm{a}$ \\
Mix 1 & $15 \mathrm{~b}$ & $527 \mathrm{a}$ & $2 \mathrm{a}$ \\
Mix 2 & $4.0 \mathrm{a}$ & $806 \mathrm{a}$ & $187 \mathrm{ab}$ \\
Mix 3 & $10.7 \mathrm{ab}$ & $837 \mathrm{a}$ & $308 \mathrm{bc}$ \\
SOIL (Control) & $3.7 \mathrm{a}$ & $775 \mathrm{a}$ & $11 \mathrm{a}$ \\
LSD & 9.35 & 4995.8 & 289.3 \\
P-Value & 0.066 & 0.032 & 0.01 \\
\hline
\end{tabular}

For each variable, means followed by the same letter are not significantly different at $\mathrm{p}=0.05$ level and exhibits similar treatment effect

Table 5. Average treatment effect on lettuce height, girth, number of leaves, wet and dry weight.

\begin{tabular}{|c|c|c|c|c|c|}
\hline Treatment & Height (cm) & girth $(\mathrm{cm})$ & No. of leaf & wet weight (g) & dry weight (g) \\
\hline Compost & $17.33 \mathrm{c}$ & $11.67 \mathrm{c}$ & $10.33 \mathrm{a}$ & $31 \mathrm{ab}$ & $1.98 \mathrm{a}$ \\
\hline DFS & $15.67 \mathrm{bc}$ & $11.1 b c$ & $12 \mathrm{ab}$ & $28.2 \mathrm{ab}$ & $1.62 \mathrm{a}$ \\
\hline M1 & $12 \mathrm{a}$ & $9.83 \mathrm{abc}$ & $13.33 b$ & $33.6 \mathrm{~b}$ & $2.09 \mathrm{a}$ \\
\hline M2 & $13 \mathrm{ab}$ & $8.5 \mathrm{a}$ & $12 \mathrm{ab}$ & $25 \mathrm{a}$ & $1.65 \mathrm{a}$ \\
\hline M3 & $13.33 \mathrm{ab}$ & $9.33 \mathrm{ab}$ & $12 \mathrm{ab}$ & $30.4 \mathrm{ab}$ & $1.93 \mathrm{a}$ \\
\hline Soil & $14 \mathrm{ab}$ & $11.5 \mathrm{c}$ & $10 \mathrm{a}$ & $23.7 \mathrm{a}$ & $1.62 \mathrm{a}$ \\
\hline LSD & 2.813 & 2.039 & 2.258 & 7.59 & 1.072 \\
\hline P-Values & 0.014 & 0.027 & 0.064 & 0.106 & 0.867 \\
\hline
\end{tabular}

LSD for comparing means at the same level of treatment (5\% level of significance): 3.1544

For each variable, means followed by the same letter are in the same range and exhibits similar treatment effect.

\section{Discussion}

\subsection{Formulation Mix Composition}

From table 1, A high significant $(\mathrm{P}=0.001)$ difference in nitrogen $(\mathrm{N})$ level were observed in various treatment. Dry fecal sludge (DFS) recorded the highest level of nitrogen among the treatments. Based on the preliminary data obtained, Nitrogen levels were predicted in mix samples (eqn1)

\subsection{Effect of Treatment on Physicochemical Characteristics of DFS, Compost and Formulated Mix}

From table 2, dry fecal sludge recording the highest N\% indicating 3.02 and compost recording the lowest $\mathrm{N} \%$ indicating 1.037 , blending the two feedstock materials recorded percentage values of 1.5, 2.13 and 2.45 indicating M 1, 2 and 3 respectively. According to LSD, there exist some similarities between treatment on percentage total nitrogen found being in the same range. M0(2) and $\mathrm{M} 1$ exhibited some similarities, same results were found between M0(3) and M 3, M 2 and 3, M0(2) and M0(1) (control) also showed some similarities between treatments on $\mathrm{TN} \%$.

There was a significant $(\mathrm{p}<0.001)$ difference in the treatments for Total Phosphorous (P) levels; according to statistical data recorded treatment gave a P-value of 0.001 indicating a high significant difference in the various treatments (table 2). The high mean phosphorous (P) level was $0.337 \%$ occurring in the soil which served as the control treatment. DFS and compost recorded values of $0.1267 \% \mathrm{P}$ and $0.018 \% \mathrm{P}$ respectively. Mixed treatments; M1, M2 and M3 recorded values of $0.063 \%, 0.008 \%$ and $0.065 \%$ respectively which showed similar treatment effect with values recorded being in the same range. There exist unique treatments effect between dry fecal sludge, compost and the control.

A significant difference $(\mathrm{P}<0.001)$ in $\mathrm{K}$ was observed in the treatments. The highest mean Potassium (K) level recorded were $4.660 \%$ and $4.653 \%$ occurring in M 1 and 2 respectively. Compost and dry fecal sludge recorded values of $3.39 \%$ and $1.47 \%$ respectively with dry fecal sludge recording the lowest value. Mix samples recorded a significant increase in $\mathrm{K}$ levels with values of $4.66 \%, 4.65 \%$ and 3.52\% indicating Mix 1, 2 and 3 respectively. Control 
sample recorded $2.28 \% \mathrm{~K}$. Mix 1 and 2 were found to be in the same range and exhibit similar treatment effect. Mixed 3 and compost also exhibited similar treatment effect on $\mathrm{K}$ as values were $\mathrm{s}$ found to be in the same range.

\subsection{Effect of Treatment on Chemical Characteristics of DFS, Compost and Mix Samples}

A highly significant $(\mathrm{p}=0.001)$ difference in total carbon levels were recorded in the various treatment showing $\mathrm{p}<0.05$ according to Duncan's' multiple range test (table 2).

Dry fecal sludge shows the highest in total carbon concentrations with a value of $35.20 \%$ followed by M3> M2> compost > M1 and Soil being the control, indicating values of $16.50 \%, 14.30 \%, 11.93 \%, 10.29 \%$ and $6.5 \%$ respectively. The high and low values of total carbon concentrations in DFS and Compost respectively in the preliminary analysis results (Table 2) predicts the total carbon levels in mix samples based on the various formulation mix ratios (Table 1)

Mix 1, 2 and 3 showed a steady increase in the total carbon content. There exist some similarities between treatments on percentage total Carbon content recorded. Control and M1, compost and Mix 1, compost and Mix 2, Mix 1 and 2, Mix 2 and 3 all exhibited some form of similarities between treatments. Dry fecal sludge exhibited completely different treatment effect.

There was a significant difference in the treatment in respect of Organic Matter content recorded, having a P- value of 0.001 at $p<0.05$ significant difference. From the results recorded, dry fecal sludge and compost recorded values of $53.7 \%$ and $35.9 \%$ respectively. There was a significant increase in organic matter content in the mix samples. Mix 2 showed maximum level of organic matter content (62.9\%). Mix samples, M1, M2, M3 and DFS exhibited similar treatment effect as found to be in the same range with values of $54.9 \%, 62.9 \%, 59.8 \%$ and $53.7 \%$ respectively. Soil sample recorded the least value of $\mathrm{OM}$ content with a value of $10.2 \%$. High percentage organic matter contents recorded in mix samples predicts that treatment samples can serve as good soil amendment. This is in support of the research that indicates that sludge with high organic matter is most beneficial in mineral soils [13]. Samples analysed meet the Israeli standard requirement according to compost classifications of 25-35 OM \% dry weight [14].

A significant difference $(\mathrm{P}<0.001)$ in Carbon: Nitrogen was observed in different treatments. Mixed samples: M1, M2 and M3 exhibited similar treatment effects, recording values of $6.74,6.71$ and 6.74 respectively (table 2); whiles compost, Dry fecal sludge (DFS) and Soil (control) also showed similar effects of treatment on $\mathrm{C} / \mathrm{N}$ ratio recording values of $11.5,11.6$ and 11.23 respectively. The $\mathrm{C}: \mathrm{N}$ obtained in the mix samples ranged between 6.7 and 7. This is in support of the research that indicates a $\mathrm{C}: \mathrm{N}$ range of this can be described as good for composting or for direct application on the land [15-16]. These also indicate that the $\mathrm{C} / \mathrm{N}$ ratios recorded (6.7-8) is characteristic of stable, or close to mature fecal sludge based compost.
Statistical analysis demonstrates that treatments had a high significant $(\mathrm{P}<0.001)$ influence on the Ash contents of the various treatments (table 2), Dry fecal sludge (DFS), mix 1, 2 and 3 are in the same range and showed similar levels of treatment effect with values of $46.3 \%, 45.1 \%, 37.1 \%$ and $40.2 \%$ respectively. The highest value of Ash content was recorded in the Soil $(89.8 \%)$ followed by compost $(64.1 \%)$ with different treatment effects.

There was a significant $(\mathrm{p}<0.001)$ differences among the treatments with respect to $\mathrm{pH}$. Mixed 2 and 3 treatments are in the same range and shows similar treatment effect on $\mathrm{pH}$. Compost and Control showed similar treatment levels with Compost recording the highest mean $\mathrm{pH}$ value of 7.70 followed by the soil sample (table 2). DFS and Mix 1 showed unique effect with no similar treatment effect. Mix 2 and 3 showed similar treatment effects recording values of 6.8 and 6.6 respectively.

Again, from table 2, moisture content showed a significant $(\mathrm{P}<0.05)$ difference in treatments with Mix 2 recording highest level, of $34.4 \%$. Formulated Mix 1and 3 showed similar treatment levels given a range of 32.3-23.7 respectively. There exist some forms of similarities between treatments with regards to $\mathrm{pH}$.

\subsection{Effect of Treatment on Metal Concentrations}

From table 3 , a highly significant $(\mathrm{p}=0.001)$ difference in Magnesium $(\mathrm{Mg})$ levels were recorded in the various treatment. The highest mean $\mathrm{Mn}$ level recorded were $0.760 \%>0.717 \%>0.625 \%$ occurring in formulated Mix 1,2 and compost respectively showing similar treatment level effects, DFS $(0.421 \mathrm{~g} / \mathrm{kg})$ and Mix $3(0.387 \mathrm{~g} / \mathrm{Kg})$ were found to be in the same range and exhibited similar treatment effect.

The Lead $(\mathrm{Pd})$ content did not show any significant $(\mathrm{P}=0.061)$ difference between treatment.. DFS, Mix3 and Mix1 were recorded to be in the same range and show similar treatment effects indicating $0.042 \%, 0.083 \%$ and $0.094 \%$ respectively. Soil (control) recorded the highest $\mathrm{Pb}$ content indicating $0.227 \%$. Compost $(0.135 \mathrm{~g} / \mathrm{Kg})$ and $\mathrm{Mix} 2$ $(0.123 \mathrm{~g} / \mathrm{Kg})$ was found to be in the same range showing similar treatment effect.

Zinc content in treatment showed highly significant $(p=0.001)$ difference in treatments. Zinc $(\mathrm{Zn})$ levels recorded in the various treatment showing P-Value less than 0.05 . The highest mean $\mathrm{Zn}$ level recorded was $1.633 \%$ occurring in compost and Mix2 (1.590) showing similar treatment level effects.

There was no significant $(\mathrm{P}=0.301)$ difference in the treatment for iron $(\mathrm{Fe})$ content. The highest recorded iron content was found in Soil $(89.8 \%)$ followed by DFS. Found in the same range was DFS, compost and Mix1showing similar treatment effect on Fe. Mix2 and Mix3 also showed similar treatment effect being in the same range.

High levels of heavy metals (e.g., $\mathrm{Cd}, \mathrm{Cr}, \mathrm{Cu}, \mathrm{Pb}, \mathrm{Ni}$ and $\mathrm{Zn}$ ) in composts represent an obvious concern if they are to be applied to food crops [13]. It should be mentioned though that, in the data obtained from analysis of heavy metal concentrations none of the chemical element exceeds the 
established maximum admissible concentrations reported in most of the African countries [17].

\subsection{Effects of Treatment on Microbial Concentrations}

From table 4, treatment concentration on Helminth Egg (HE) showed no significant effect, recording p-value greater than 0.05. However Helminth egg concentration decreases from range value of $15 / 20 \mathrm{~g}$ to $2 / 20 \mathrm{~g}$ indicating Mix 3 and Compost respectively. Compost, Soil (control) and Mix 2 were found to be in the same range and exhibited similar treatment effect with values recording $2 \mathrm{egg} / 20 \mathrm{~g}, 3.7 \mathrm{egg} / 20 \mathrm{~g}$ and $4 \mathrm{egg} / 20 \mathrm{~g}$ respectively. Dry fecal sludge and Mix 3 also exhibited similar treatment effect.

Reading from table 4, there were significant differences in the treatments for Fecal Coliform (FC) and E.Coli as their pvalues were less than 0.05. From the results obtained treatments exhibited similar treatment effects. Dry fecal sludge (DFS), Mix 1, 2, 3 and soil (control) were found to exhibit similar treatment effect with values found to be in the same range. Compost and mix 3 also exhibited some similarities between treatments. The highest mean fecal coliform level recorded was $8279 \mathrm{cfu} / \mathrm{g}$ occurring in compost.

The statistics on the effect of treatment composition on $E$. coli did prove significant $(\mathrm{P}=0.010)$ effect on treatments. The treatments: DFS, Mix1, 2 and control were found to be in the same range showing similar effect. The highest treatment effect on E.coli was recorded in compost. Compost and Mix 3 also showed similar treatment effect recording values of $524 \mathrm{cfu} / \mathrm{g}$ and $308 \mathrm{cfu} / \mathrm{g}$ respectively.

The results of this study showed a higher maximum microbial concentration levels compared to international approved standards. The different high levels of microbial concentrations point to the fact that compost did not mature during the composting process and DFS not properly sanitized or dried (Three months drying process) for a longer period.

\subsection{Effect of Treatment on Lettuce Height, Girth, Number of Leaves Wet and Dry Weight}

The effect of treatment on plant height, girth, number of leaves, wet and dry weight recorded demonstrates that: there was a significant $(\mathrm{p}<0.05)$ variation in means, in lettuce height and width. Number of leaf, wet and dry weight showed no significant ( $\mathrm{p} \geq 0.05$ ) differences (table 5). From the results maximum plant height was observed in compost $(17.33 \mathrm{~cm})$ and Dry fecal sludge recorded a value of $15.67 \mathrm{~cm}$. Mix samples exhibited similar treatment effect with values of $12 \mathrm{~cm}, 13.3 \mathrm{~cm}$ and $14 \mathrm{~cm}$ indicating Mix 1,2 and 3 respectively.

From table 5, the Compost, dry fecal sludge and control (soil) were found to be in the same range exhibiting similar effect on plant width recording values of $11.7 \mathrm{~cm}, 11.1 \mathrm{~cm}$ and $11.5 \mathrm{~cm}$ respectively. There exist a lot of similarities between treatments in terms of lettuce width. Dry fecal sludge, Mix 1, 2 and 3 exhibited similar treatment effects. Control treatment, compost and DFS were also found to be in the same range and exhibited similar treatment effects.

\section{Conclusion}

The study revealed that sun-drying of dewatered fecal sludge is an effective means of reducing the pathogens and other toxic compounds found in raw sewage sludge. Dewatered fecal sludge from the Lavender Hill Fecal Treatment Plant recorded an average mean value of $4 \times 10^{7}$ egg $/ 20 \mathrm{~g}$ and $4 \times 10^{4} \mathrm{cfu} / \mathrm{g}$, indicating helminth egg and fecal coliform respectively. The final Dry Fecal Sludge had a better nutrient balance $(\mathrm{N}, \mathrm{P}, \mathrm{K} \mathrm{OM})$ with reduce content of pathogens ( fecal coliform, E. coli and Helminth egg) and metal concentrations although the content of pathogens found after treatment were still higher compared to required legislation. High microbial levels in compost could be attributed to immature compost during the composting process. The concentrations /of metals analyzed in dried fecal sludge, compost and formulated mix were too low to be source of concern when the biosolids are to be considered as soil amendment.

The study showed that there was a significant difference on physicochemical characteristics (OM, C, N, P, and K) of mix samples. Mix 1, 2 and 3 recorded Total Nitrogen Content values of $1.53 \%, 2.13 \%$ and $2.50 \%$ respectively, indicating good nitrogen range blending the two materials. Organic Matter (OM) content in mix 1, 2 and 3 increased significantly recording values of $54.93 \%, 62.90 \%$ and $59.77 \%$ respectively with regards to compost and Dry Fecal Sludge. The study revealed an increase in potassium content with a range value of $3.5 \%-4.7 \%$ with and initial value of $1.47 \%$ in DFS and $3.39 \%$ in compost.

There was a significant $(\mathrm{p}<0.05)$ variation in means, in lettuce height and width. Supplementing Dry fecal sludge (high nitrogen content) with Compost (low nitrogen content) has shown to be a good approach, complementing the capacity of each growing media and becomes very essential for use by farmers as soil fertility improvement materials.

Future, research should consider the factor of post planting application of amendments to lettuce and other vegetable.

\section{References}

[1] Sandec. (2015). Faecal Sludge Collection and Transport at Kigamboni in Dar es Salaa, Tanzania.

[2] Kone, D., \& Peter, S. (2014). Faecal Sludge Management, pp35.

[3] Gbenatey, N. E. (2013). Faecal Sludge Reuse in Urban and Peri-urban Crop Production.

[4] MWRWH. (2009). Water and Sanitation Sector Performance Report Water and Sanitation Sector Performance Report.

[5] Gss. (2013). 2010 Population \& Housing Census Report. Millennium Development Goals In Ghana.

[6] GSS. (2014). District Analytical Report, Accra Metropolitan. Maks Publications \& Media Services. Retrieved from $\mathrm{http} / /$ ghanadistricts.com/districts 
[7] Issahaku Ahmed, Ama Mbeaba Quarshie, Dennis OforiAmanfo, Florence Cobbold, Eric Simon Amofa-Sarkodie, Esi Awuah. Assessment of Foreign Material Load in the Management of Faecal Sludge in the Greater Accra Region of Ghana. International Journal of Energy and Environmental Science. Vol. 3, No. 1, 2018, pp. 27-36. doi: $10.11648 / j$.ijees.20180301.13

[8] Jiménez, B., Mara, D., \& Carr, R. (2008). Wastewater Treatment for Pathogen Removal and Nutrient Conservation: Suitable Systems for Use in Developing Countries. Iwmi, 150-169. http://doi.org/10.4324/9781849774666

[9] Impraim, R., Nikiema, J., Cofie, O., \& Rao, K. (2014). Value from faecal sludge and municipal organic waste: fertilizer cum soil conditioner in Ghana. Retrieved from https://cgspace.cgiar.org/handle/10568/67611

[10] L. P. Van Reeawijk, (1992). Procedures for soil analysis. International soil reference $\&$ information, $3^{\text {rd }}$ edition Wageningen- the Netherlands.

[11] APHA, AWWA, WEF, (2012 Standard Methods for the examination of water and wastewater, $22^{\text {nd }}$ Edition Washington, D. C.

[12] Schwartzbrod j (1998) method of ananlysis of Helminth Eggs and Cysts In Wastewater, Sludge, Soil And Crops University Henry Poincare, Nancy.
[13] Rockson, G. N. K, (2014). Composting of Abattoir Waste and River Reed: Effect of Feedstock and Aeration Mechanism on Process Efficiency. PhD, Kwame Nkrumah University of Science and Technology, Department of Agricultural Engineering.

[14] Yona Chen, Jorge Tarchitzky (2009), Physico-chemical Properties of Biosolids Produced by Aerobic Liquid Digestion Employing the ThermAer Second Generation ATAD Process Research Report Submitted to WCI Environmental Solution Inc. Rehot, Israel. http://www.wcienvironmental.ca/wpcontent/uploads/Physico chemical_Properties_of_ThermAer_biosolids.pdf.

[15] Baffour A. E. (2009). Co-composting of Dewatered fecal sludge (BIOSOLIDS) and sawdust for agricultural use as an organic fertilizer: A case study of the KNUST sewage treatment plant. MSc, Kwame Nkrumah University of Science and Technology, Colledge of Science, Faculty of Biosciences.

[16] Moritz Gold, Charles Niwagaba, Florian Studer, Wim Getkate, Mohammed Babu, Linda Strande (2015). Resource recovery from faecal sludge treatment endproducts could help offset faecal sludge treatment costs. Excreta and Wastewater Management; Sandec News 16.

[17] Adamtey, N., Cofie, O., Ofosu-Budu, K. G., Ofosu-Anim, J., Laryea, K. B., \& Forster, D. (2010). Effect of N-enriched cocompost on transpiration efficiency and water-use. 